\title{
Water and ecological resource governance: the GBB context
}

\author{
M. Anwar Hossen ${ }^{*}$
}

*Correspondence:

anwar_sociology@yahoo.com Department of Sociology,

Dhaka University-Bangladesh,

Dhaka, Bangladesh

\section{Background}

Water governance is emerging approach to restore the Ganges-Brahmaputra Basin (GBB) ecosystems and secure community livelihoods. By governance, I mean a process that allows community voices to be included in the GBB management policy and implementation processes. This governance is described as a participatory approach that can recognize spatial and temporal aspects. To execute any water development project, it is important to consider diverse community voices regarding the ecosystem that ranges from the Himalayan Mountains to the Bay of Bengal. Temporal data like historical water flows, croplands, and community diversities can be helpful for promoting this ecosystem. For this purpose, political ecological perspective emphasizes on a pluralistic approach based on the inclusion of GBB countries with coordinated relationships between nature, politics and science. These relationships based on the governance approach can be helpful for promoting environmental sustainability and community empowerment.

In order to determine what type of governance approach would be practical and realizable in the context of GBB political geography and hydropolitics, this proposed special issue focuses on the questions: what are the major mechanisms in reducing hydropolitical domination over the upstream and downstream political geography? How can the ecological integrity and common ecological resources be protected with the governance approach? What are the challenges for community voice inclusion in water policy formulation and implementation processes at local and the basin levels? Based on these questions, as Guest Editor of Bandung: Journal of the Global South, I published a call for paper on Water and ecological resource governance: the GBB context at international level. With rigorous review of the received papers, I was able to recommend five articles for publication which cover the subject matters of political geography of the GBB and hydropolitics, water development practices at the GBB upstream or downstream countries and their effects on local communities, the ecological integrity and common ecological resource governance, review of the current basin management institutions, and challenges for community participation in local and the basin levels. All of these issues and concerns are described with social science perspectives. 


\section{Social sciences approach to understand the GBB governance}

Although community and nature maintain a close bond historically, policy makers tend to exclude community understanding of the nature and execute the top-down water development approach. We, sociologists and anthropologists, frequently encounter the questions from our colleagues, for example, "What are you doing with water as this issue is a subject matter of other disciplines like hydrology or biology?" This stereotypical belief needs to be dropped off to understand the bond between community and nature if the policy makers really want to see a sustainable development and community empowerment.

Social science perspectives, more specifically, sociological and anthropological approach can develop a better understanding of water policy and governance. Unfortunately, these perspectives are marginalized from the mainstream analyses of water and ecological resource governance although the river bank communities are the main focus of the basin development. Based on this exclusion, the top-down approach believers are spending multi-million dollars for the different water projects with the goals of local development, poverty reduction, and community empowerment that fails to understand the bond between local community and nature. Consequently, many local communities have encountered displacements and survival challenges.

This special issue of the journal, Bandung: Journal of the Global South, is a major effort to apply social science perspectives with a specific title, Water and ecological resource governance: the GBB context. The findings of this issue argue that the governance approach can reduce the existing hydropolitical domination and promote ecological integrity for sustainable development and community empowerment.

The governance approach describes the concepts of watershed and ecological embeddedness encompassing forest, wetland, seasonal aspect, cropping season, and vegetation as ecosystem products (Hossen 2015). The basin countries need to protect this system for environmental conservation and community sustainability. For this purpose, the governance approach can recognize locally embedded ecological knowledge of borsha and khora. This knowledge requires epistemological recognition in the basin-wide institutional system as stated by Van Eijck and Roth (2007: 933) and Kottak (1999: 27).

For this purpose, social science perspectives can play a major role in representing community voices regarding the ecosystems of seasonal patterns, river flow, ecological resources, land use patterns, and crop production for the goal of community empowerment and environmental conservation. Based on these objectives, I was successful in getting positive review comments for the five papers that address many of the key points of ecosystems, current concerns, and their effects on local communities.

\section{Governance approach in the GBB context}

The GBB ecological integrity appears to be the foundation for the ecosystems and community livelihoods that can be promoted with proper water and ecological resource governance. The GBB originates from the Himalayan Mountains, flows through China, Nepal, Bhutan, India, and Bangladesh, and ends in the Bay of Bengal. The Ganges Basin originates from these Mountains in India and Nepal, and develops a specific ecological integrity and this moves forward to Bangladesh and merges with the Brahmaputra Basin at Shibalaya Sub-district. The Brahmaputra Basin originates from the northern slope 
of the Himalayas and flows eastward in China where it is known as the Tsangpo. The southward course of the Tsangpo flows in India and moves downstream towards Bangladesh, and merges with the Ganges Basin in Bangladesh. This GBB ecological integrity is a foundation for local hydrological patterns, ecological systems, and floodplain livelihood practices throughout the basin area.

However, a major governance challenge emanates from the different political jurisdictions as the GBB shares with five independent countries in the region. No country respects this integrity which causes like irregular flooding, drought, salinity intrusion, and embankment failures. The disastrous impacts from a specific water development project like the Farakka Barrage can be considered as a foundation for the argument that the ecological integrity is one of the prerequisites for protecting the common ecological resources. The bilateral basin management institution: e.g., Joint River Commission (JRC) between Bangladesh and India fails to overcome the ecological concerns.

A basin-wide governance institution can instead play a pragmatic role. This institution at local, national, and basin levels can recognize river bank community voices. Success in this governance approach can promote success in ecological integrity and community livelihoods. This approach is essential for the vast majority of people in this region who match cropping strategies effectively during both rainy and summer seasons, utilize a variety of ecological resources during times when agricultural production is limited, and get employment opportunities. Hossen and Wagner (2016) focus on this approach based on their paper The Need for Community Inclusion In Water Basin Governance in Bangladesh. In this paper the authors describe "the principle of community inclusion in water and ecological resource governance and document the negative impacts" based on Hossen's Ph.D. fieldwork 2011-12 in Chapra village, Bangladesh. The authors emphasize on community inclusion in governance processes for reducing the current challenges and for protecting ecological integrity and common property resources.

However, the Government of India does not seem to recognize this policy approach which is evident in the context of Farakka Barrage, Tipaimukh dam, and National River Linking Project. Consequently, local communities are encountering survival challenges in the form of displacements that are major reasons for local movements. Islam and Islam (2016) describe these movements in the context of Tipaimukh dam in northeast India which is one kilometre north of Bangladesh's north-eastern border. As the authors inform us, the effects of this dam would dry up two important rivers, the Surma and the Kushiara, in Bangladesh. The Indian policy prompts massive protests in local, regional, and international levels which are described by the authors as the "environmentalism of the poor."

On a national level, the government in Bangladesh needs to promote bottom-up water and agriculture policies based on theoretical guidelines of waterscapes and sociolecological systems. In this context, local community voices should get main priorities in the policy formulation and implementation processes rather than the current unilateral or bilateral approach. Khan et al. (2016) in their article Effective Supervision of Inland Capture Fisheries of Bangladesh and its Hurdles in Managing the Resources describe the importance of these priorities. The authors describe challenges and opportunities of this approach based on management of waterbodies across the different locations. This 
article is also helpful for understanding the development approach from below that is relevant for the other marginalized communities of GBB.

In this context, Akter (2016) in her article Conceptualizing Environmental Governance on the GBM Basin describes the major difficulties of promoting the governance approach. Considering the hydropolitical of upstream and downstream countries, the author applies Rittberger et al. (2006) explanatory model to explore potential scopes of GBM water governance and to promote sustainable development.

This scope needs to be recognized by political governments of the GBB and develops some major common grounds. However this recognition is not an easy task as every country has their own agenda that is developed with history, culture, and politics. Kawser and Samad (2016) in their article Political History of Farakka Barrage and Its Effects on Environment in Bangladesh describe this cultural politics. They argue that the GBB manaement between India and Bangladesh depends on political economy that represents historical legacies of colonialism, independence, language, and religion which create some commonalities and differences. Based on common economic ground, the authors emphasize on ecological integrity that is important prerequisite for water and ecological resource governance.

\section{Conclusion}

Water and ecological resource governance rather than the current top-down water approach system is essential to protect the GBB ecological integrity and promote community livelihoods. Representations of local communities on the basin governance can promote the governance approach. In order to create scopes for promoting community voices at local, national, and international levels, the GBB countries need to recognize negative effects of unilateral or bilateral water development projects. This recognition can be helpful for establishing a basin-wide institution. No water development projects could be implemented in the basin without approval of this institution that can secure environmental sustainability and community empowerment. This special edition has attempted to conceptualize this approach so that we can enhance new discourse of the GBB governance.

Received: 24 November 2016 Accepted: 29 November 2016

Published online: 06 December 2016

\section{References}

Akter, M. 2016. Conceptualizing environmental governance on the GBM basin. Bandung Journal of the Global South 3: 25

Hossen, M.A., and J. R. Wagner. 2016. The need for community inclusion in water basin governance in Bangladesh. Bandung: Journal of the Global South 3: 18

Hossen, M.A. 2015. The ganges basin management and community empowerment. Bandung: Journal of the Global South 1 (4): 1-16.

Islam, M. S., and M. N. Islam. 2016. "Environmentalism of the poor": the Tipaimukh dam, ecological disasters and environmental resistance beyond borders. Bandung: Journal of the Global South 3: 27.

Kawser, M. A., and M. A. Samad. 2016. Political history of Farakka Barrage and its effects on environment in Bangladesh. Bandung: Journal of the Global South 3: 16.

Khan, A.F., M. G. Mustafa and M. N. Naser. 2016. Effective supervision of inland capture fisheries of Bangladesh and its hurdles in managing the resources. Bandung: Journal of the Global South 3: 17.

Kottak, C.P. 1999. The new ecological anthropology. American Anthropologist, New Series 101 (1): 23-35.

Van Eijck, M., and W. Roth. 2007. Keeping the Local Local: recalibrating the status of science and traditional ecological knowledge (TEK) in education. Science Education 91 (6): 926-947. 